\title{
PENGARUH EARNING PER SHARE, KEBIJAKAN DIVIDEN, ARUS KAS, LEVERAGE DAN RETURN ON ASSETS TERHADAP NILAI PERUSAHAAN PADA PERUSAHAAN PROPERTY DAN REAL ESTATE YANG TERDAFTAR PADA BURSA EFEK INDONESIA
}

\author{
Angelin Chandra ${ }^{1}$, Arie Pratania Putri ${ }^{2}$, Leoni Angela ${ }^{3}$, Henny Puspita ${ }^{4}$, Felicia Auryn ${ }^{5}$, \\ Faby Clariesta Jingga ${ }^{6}$
}

Program Studi Akuntansi, Universitas Prima Indonesia, Jalan Belanga No.1, Medan, Sumatera Utara, 20118.

E-mail : hennyskripsi@yahoo.com

\begin{abstract}
The research was conducted in order to add insight and to find out whether Earning per Share, Dividend Payout Ratio, Cash Flow, Leverage, Return on Assets affect the value of company in property and real estate sector companies listed on Indonesia Stock Exchange for the 2013 - 2017 period. There are 75 companies and 15 sample companies that we obtained from this study using purposive sampling techniques. Descriptive quantitative is used in this type of research. The results showed that Earning Per Share, Dividend Payout Ratio, Debt to Equity Ratio and Return On Assets partially had a positive effect on firm value in property and real estate companies. While Cash Flow has no effect and is not significant. Keywords : earning per share; dividend payout ratio; cash flow; leverage; return on assets
\end{abstract}

\section{PENDAHULUAN}

Para pengusaha tentunya mempunyai tujuan ketika mendirikan suatu perusahaan.Tujuan utama tentunya adalah menjadikan perusahaan maju dan mempunyai nilai perusahaan yang tinggi. Ketika suatu perusahaan sedang dimasa jayanya, tentunya akan berdampak pada harga saham dan akan mempengaruhi nilai perusahaan menjadi tinggi. Hal ini akan menarik investor atau pemegang saham dan meningkatkan kepercayaan yang tinggi pula. Persaingan bisnis sektor property dan real estate merupakan peluang besar para investor dimana investasi ini merupakan investasi jangka panjang. Beberapa fenomena pada sektor ini sebagai berikut : (1) Pasca krisis moneter di Indonesia, tingkat pertumbuhan sektor property dan real estate semakin tinggi dengan adanya pembangunan gedung kantor dan perdagangan. (2) Dalam industri bisnis ini dikenal memiliki siklus yang sangat cepat berubah menjadi kompleks dan presistensi, pastinya juga akan mempengaruhi tingkat nilai perusahaan property dan real estate. (3) Pada tahun 2000, di negara Indonesia khususnya sektor property dan real estate mulai diminati banyak orang. Perkembangan property yang terjadi menandakan adanya perubahan perekonomian.Peningkatan mencapai hingga $10 \%$ per tahunnya dan disebabkan oleh sector property dan real estate.

Keuntungan berupa lembar saham yang dibagikan kepada para pemegang saham disebut Earning per Share. Semakin banyak lembar saham yang dibagikan maka semakin tinggi nilai perusahaan dan sebaliknya pembagian dividen yang rendah dapat menurunkan nilai perusahaan. Kebijakan dividen merupakan keputusan direksi apakah laba bersih perusahaan akan dibagikan kepada para pemegang saham atau laba tersebut akan ditahan sebagai penambahan modal perusahaan di masa yang akan datang. Jika dividen yang dibayarkan lambat dan tidak wajar, maka investor tidak akan tertarik menanamkan sahamnya dan nilai perusahaan akan menurun.

Kemampuan arus kas menggambarkan tiap aktivitas yang dilakukan di dalam perusahaan. Oleh karena itu arus kas tersebut dapat mempengaruhi penilaian investor, 
sehingga merubah harga dan mempengaruhi return yang diterima oleh investor.Leverage merupakan rasio yang melihat seberapa besar beban hutang yang ditanggung oleh perusahaan dibandingkan dengan aktivanya. Para investor akan melihat hutang sebagai modal dan kemungkinan untuk menghasilkan laba jika rasio leverage tinggi.Rasio yang mengukur aset yang dimiliki agar dapat menghasilkan laba bagi perusahaan dan jika semakin tinggi laba yang dihasilkan maka perusahaan akan meningkat, ini disebut rasio return on assets.

\section{TINJAUAN PUSTAKA}

Pengaruh variabel earning per share terhadap nilai perusahaan. Jika pendapatan para pemegang saham semakin besar maka dividen mengalami kenaikan, disebut earning per share. (Darmadji dan Fakhruddin, 2012:154). Para investor akan mengevaluasi performance dari suatu perusahaan apakah mengalami kenaikan atau penurunan. Perusahaan yang besar dan sukses umumnya mempunyai rasio earning per share yang tinggi dan hal ini berdampak pada Price to Book Value (PBV) yang akan mengalami kenaikan. (Marlina, 2013). Laba perusahaan diukur dari setiap saham yang beredar selama periode tertentu dan rasio ini menunjukkan kemampuan perusahaan dalam meraih laba bersih bagi pemegang saham atas lembar saham yang diinvestasikan. Semakin besar tingkat kemampuan perusahaan dalam menghasilkan laba maka semakin untung dan menarik bagi para investor terhadap perusahaan tersebut. (Margaretha, 2011:5).

$H_{1}$. Earning Per Share berpengaruh positif terhadap nilai perusahaan.

Pengaruh variabel kebijakan dividen terhadap nilai perusahaan. Jika dividen dibayar secara tunai maka kebijakan dividen semakin meningkat, dana yang tersedia semakin sedikit untuk investasi kembali. Dampak buruk bagi pertumbuhan di masa depan menjadi rendah, sehingga akan menekan harga saham. (Ahmad dan Ali, 2014:116). Jika dividen dibayarkan secara lancar dan wajar, maka para investor pasti akan tertarik dan nilai perusahaan semakin meningkat (Jusriani, 2013:47). Kebijakan dividen yang terlampau besar akan merugikan harga saham perusahaan. Perubahan besarnya mengandung dua akibat yang saling bertentangan. Jika kebijakan dividen optimal maka akan seimbang dan memaksimalkan harga saham. (Margaretha, 2011:142).

$\mathrm{H}_{2}$. Kebijakan dividen berpengaruh positif terhadap nilai perusahaan.

Pengaruh variabel arus kas bebas terhadap nilai perusahaan. Kemampuan indikasi Arus kas bebas (free cash flow) perusahaan diukur dari pembayaran utangnya, dividen, pembelian saham. Menurut Benardi (2010), semakin tinggi arus kas yang tersedia maka nilai perusahaan pasti akan mengalami kenaikan dan begitu juga sebaliknya. Perusahaan dengan free cash flow tinggi akan memiliki kinerja yang lebih baik sehingga semakin tinggi nilai perusahaan dibandingkan perusahaan lain maka keuntungan yang diperoleh mungkin tidak dapat diperoleh oleh perusahaan lain. (Dewi dan Putra, 2017). Jika nilai perusahaan meningkat dan arus kas menurun maka perusahaan memiliki return positive (Mardasari, 2014 ).

$\mathrm{H}_{3}$.Arus Kas Bebas berpengaruh positif terhadap nilai perusahaan.

Pengaruh variabel leverage terhadap nilai perusahaan. Hutang berpengaruh bagi perusahaan karena mempunyai beban yang bersifat tetap. Jika perusahaan tidak mampu membayar bunga hutang maka perusahaan akan mengalami kebangkrutan. Sebaliknya penggunaan hutang juga dapat menguntungkan bagi pemegang saham karena memberikan deduksi pajak atas bunga. (Indriani, 2018:42). Jika suatu perusahaan pendanaannya semakin tinggi maka resiko hutang semakin besar daripada equity (modal sendiri), disebut Debt to Equity Ratio. Leverage perusahaan pasti memiliki pengaruh negatif terhadap nilai perusahaan karena menggunakan hutang sebagai struktur permodalan perusahaan. (Nurminda et al., 2017:544). Kalau tingkat resiko hutang tinggi, maka perusahaan juga berskala besar sehingga para investor akan tertarik menanamkan saham pada perusahaan tersebut. (Nisa, 2017:48). 
$H_{4}$. Leverage berpengaruh positif terhadap nilai perusahaan.

Pengaruh variabel return on assets terhadap nilai perusahaan. Perusahaan dengan tingkat profitabilitas yang tinggi mampu memberikan return yang tinggi bagi para investor karena secara khusus meningkatkan harga saham nilai perusahaan dan bisa membayar tingkat persen bunga pokok pinjaman. (Pantow et al., 2015:10). Jika pengembalian atas aset tinggi berarti semakin tinggi pula jumlah laba bersih yang dihasilkan dan sebaliknya jika semakin rendah hasil pengembalian atas aset berarti semakin sedikit jumlah laba bersih yang dihasilkan dari total aset. (Hery, 2017:193). Kenaikan nilai perusahaan terjadi karena pembayaran bunga atas hutang merupakan pengurangan pajak. Oleh karena itu jika laba operasi yang diterima investor lebih besar maka nilai perusahaan juga akan lebih besar. (Kamaludin, 2012:321).

$\mathrm{H}_{5}$. Return On Assets berpengaruh positif terhadap nilai perusahaan.

$\mathrm{H}_{6}$. Earning Per Share, Divident Payout Ratio, Free Cash Flow, Debt To Equity Ratio, Return On Assets berpengaruh terhadap Price To Book Value.

\section{METODE PENELITIAN}

Pendekatan kuantitatif dalam metode penelitian Sugiyono (2010:7) ini berupa angka dan menggunakan statistik untuk menganalis penelitian. Menurut Anwar (2014:14) menggunakan deskriptif kuantitatif karena menjelaskan fakta dengan hasil olahan data untuk meneliti jenis metode penelitian. Sifat penelitian Zulganef (2013:11) menggunakan explanatory research karena untuk menelaah kausalitas hubungan atau pengaruh antar variabel yang menjelaskan suatu fenomena tertentu.Teknik dari pengumpulan data yang kita peroleh adalah dengan melalui studi dokumentasi dan juga mengumpulkan data sekunder dari laporan keuangan perusahaan sektor properti dan real estate yang tercatat di Bursa Efek Indonesia tahun 2013-2017.

Populasi dan sampel. Populasi merupakan kawasan yang sama dimana didalamnya terdiri dari obyek ataupun subyek yang mempunyai kualitas tertentu dan ditetapkan oleh peneliti (Sugiyono 2010:115). Populasi dalam penelitian ini adalah perusahaan yang bergerak di sektor Property dan Real Estate dan sebanyak 75 perusahaan yang diperoleh. Sedangkan sampel merupakan sebagian dari jumlah populasi yang berjumlah 15 Perusahaan dalam periode 5 tahun. Beberapa kriteria sampel dengan menggunakan teknik sampling purposive adalah:(1) perusahaan property dan real estate yang terdaftar di BEI pada periodik 20132017; (2) perusahaan property dan real estate yang menerbitkan financial report secara berturut-turut pada periodik 2013-2017; dan (3) perusahaan property dan real estate yang membagikan dividen secara continue pada periodik 2013-2017. Tabel 1 menyajikan identifikasi dan definisi operasional variabel penelitian. 
Tabel 1. Identifikasi dan definisi operasional variabel penelitian

\begin{tabular}{|c|c|c|c|}
\hline Variabel & Definisi & Indikator & Pengukuran \\
\hline Earning per share $(\mathrm{X} 1)$ & $\begin{array}{l}\text { EPS yaitu pendapatan per } \\
\text { lembar saham yang dapat } \\
\text { dilihat di laporan laba rugi. } \\
\text { (Murhadi, 2013:64) }\end{array}$ & $\begin{array}{l}E P S=\text { Laba bersih } \\
\text { setelah pajak:Penjualan } \\
\text { saham biasa } \\
(\text { Samryn, 2015:425) }\end{array}$ & Rasio \\
\hline Kebijakan dividen (X2) & $\begin{array}{l}\text { Pemegang saham akan } \\
\text { mendapatkan laba sebagai } \\
\text { dividen tapi akan ditahan untuk } \\
\text { investasi disebut kebijakan } \\
\text { dividen. (Musthafa, 2017: 141) }\end{array}$ & $\begin{array}{l}\text { DPR }=\text { Dividend: } \\
\text { Earning After Taxes } \\
\text { (Purwanto, 2017:27) }\end{array}$ & Rasio \\
\hline Arus kas (X3) & $\begin{array}{l}\text { Arus kas memperlihatkan rasio } \\
\text { sampai sejauh mana margin } \\
\text { laba operasi dapat menutupi } \\
\text { kebutuhan keuangan. } \\
\text { (Yuniningsih, 2018:52) }\end{array}$ & $\begin{array}{c}\text { Arus kas }=\text { Arus kas } \\
\text { masuk - Arus kas keluar } \\
\text { (Utari et al., 2016:123) }\end{array}$ & Nominal \\
\hline Leverage $(\mathrm{X} 4)$ & $\begin{array}{l}\text { Leverage merupakan rasio yang } \\
\text { digunakan untuk mengukur } \\
\text { berapa besar aktiva perusahaan } \\
\text { dibiayai dengan hutang atau } \\
\text { pihak luar (Najmudin, 2011:86) }\end{array}$ & $\begin{array}{l}D E R=\text { Total Hutang } \\
\text { Total Ekuitas } \\
\text { (Sujarweni, 2016:133) }\end{array}$ & Rasio \\
\hline Return on assets (X5) & $\begin{array}{l}R O A \text { mengukur penggunaan } \\
\text { perusahaan atas asetnya untuk } \\
\text { menghasilkan laba. (Harrison, } \\
\text { et al., 2013:30) }\end{array}$ & $\begin{array}{c}R O A=\text { Laba bersih } \\
\text { sesudah pajak : Total } \\
\text { aktiva. (Sjahrial, } \\
\text { 2012:46) }\end{array}$ & Rasio \\
\hline Nilai perusahaan $(\mathrm{Y})$ & $\begin{array}{l}\text { Nilai perusahaan dikenal } \\
\text { sebagai penjumlahan nilai dari } \\
\text { utang dan ekuitas perusahaan. } \\
\text { (Ahmad dan Ali, 2014:130) }\end{array}$ & $\begin{array}{c}P B V=\text { Harga Pasar } \\
\text { Saham : Nilai Buku } \\
\text { Saham. (Sugiyono, } \\
\text { 2016:70) }\end{array}$ & Rasio \\
\hline
\end{tabular}

\section{Uji asumsi klasik}

Uji normalitas. Variabel diuji untuk mengetahui apakah variabel berdistribusi normal atau tidak. Ghozali (2013:110) menggunakan grafik histogram dan P-Plot untuk mendekati distribusi atau residual normal. Analisis statistik menggunakan Uji Kolmogorov-Smirnov, jika nilai signifikansi > 0,05 maka data residual berdistribusi normal.

Uji multikolinearitas. Keadaan di mana model regresi ditemukan adanya korelasi yang sempurna antar variabel independen. Priyatno (2012:151) menyatakan variabel bebas memiliki nilai VIF kurang dari 10 dan Tolerance Value diatas 0,10 maka tidak ada masalah.

Uji autokorelasi. Ghozali (2013:110-111) menggunakan uji ini untuk mengetahui apakah ada gangguan korelasi atauautokorelasi karena kesalahan spesifikasi. Untuk menguji speksifikasi digunakan nilai Durbin Watson. Jika $\mathrm{du}<\mathrm{dw}<4-\mathrm{du}$, maka tidak menimbulkan masalah.

Uji heteroskedastisitas. Ketidaksamaan varian dari residual model regresi atau dengan keputusan dilihat dari grafik Scatterplot. Menurut Ghozali (2013:139), jika titik - titik menyebar secara acak baik diatas maupun dibawah angka 0 dan sumbu Y maka tidak ada masalah. Analisis statistik metode lain yaitu menggunakan uji park, tidak akan menimbulkan masalah jika nilai signifikan $>0,05$. 
Model penelitian. Pengaruh variabel bebas dan variabel digunakan rumus regresilinear berganda yaitu :

Keterangan :

$$
Y=\alpha+\beta_{1} X_{1}+\beta_{2} X_{2}+\beta_{3} X_{3}+\beta_{4} X_{4}+\beta_{5} X_{5}+\varepsilon
$$

$\alpha=$ Konstanta

$\mathrm{Y}=$ Nilai perusahaan

$\beta 1=$ Koefisien regresi variabel X1 (earning per share)

$\beta 2=$ Koefisien regresi variabel $\mathrm{X} 2$ (kebijakan dividen)

$\beta 3=$ Koefisien regresi variabel X3 (arus kas)

$\beta 4=$ Koefisien regresi variabel X4 (leverage)

$\beta 5=$ Koefisien regresi variabel X5 (return on assets)

$\mathrm{X} 1=$ Variabel earning per share

$\mathrm{X} 2=$ Variabel kebijakan dividen

$\mathrm{X} 3=$ Variabel arus kas

$\mathrm{X} 4=$ Variabel leverage

$\mathrm{X} 5=$ Variabel return on assets

Koefisien determinasi. Digunakan variabel terikat agar mampu mengukur varian dan variabel bebas. Jika kemampuan nya semakin besar, maka peluang untuk menerangkan variabel terikat semakin tinggi.

Pengujian hipotesis secara simultan (Uji F). Menguji apakah variabel independen berpengaruh secara bersamaan terhadap variabel dependen. Jika $F$ hitung $>F$ tabel untuk tingkat signifikan $\alpha=5 \%$, maka variabel bebas secara bersama-sama berpengaruh terhadap variabel terikat.

Pengujian hipotesis secara parsial (Uji t).Pengaruhnya adalah variabel independen secara individual terhadap variabel dependen. Jika $t$ hitung $>\mathrm{t}$ tabel atau - $\mathrm{t}$ hitung $<-\mathrm{t}$ tabel untuk tingkat signifikan $\alpha=5 \%$, maka variabel bebas secara parsial berpengaruh terhadap variabel terikat.

\section{HASIL PENELITIAN DAN PEMBAHASAN}

\subsection{Hasil penelitian}

Statistik deskriptif. Analisis ini untuk mengetahui nilai minimum, maksimum, ratarata, maupun standar deviasi setiap variabel.

Tabel 2. Statistik deskriptif

\begin{tabular}{lrrrrr}
\hline & N & \multicolumn{1}{c}{ Minimum } & \multicolumn{1}{c}{ Maximum } & Mean & \multicolumn{1}{c}{ Std. Deviation } \\
\hline Earning per share & 75 & 11.420 & 1256.880 & 153.57413 & 229.199082 \\
Dividend payout ratio & 75 & 0.020 & 3.720 & 0.32053 & 0.505531 \\
Arus kas bebas & 75 & 84490346000 & 6109239577200 & 628635779454711.60 & 1354353995349307.000 \\
Debt to equity ratio & 75 & 0.240 & 5.280 & 1.38587 & 1.208592 \\
Return on asset & 75 & 0.010 & 0.220 & 0.07573 & 0.043687 \\
Nilai perusahaan & 75 & .290 & 11.950 & 2.67680 & 2.146805 \\
Valid N (listwise) & 75 & & & & \\
\hline
\end{tabular}

Tabel 2 menampilkan nilai minimum, maksimum, rata-rata (mean), dan standar deviasi dari variabel earning per share, dividend payout ratio, arus kas bebas, debt to equity ratio, return on asset dan nilai perusahaan dengan rincian sebagai berikut:

1. Dari sampel sebanyak 75, Earning Per Share mempunyai nilai minimum 11,420 pada PT. Plaza Indonesia Realty Tbk pada tahun 2013 dan nilai maksimum 1256,880 pada PT. Metropolitan Kentjana Tbk pada tahun 2016 sedangkan rata-rata (mean) 153,57413 dengan standar deviasi 229,199082. 
2. Dari sampel sebanyak 75 , Dividend Payout Ratio mempunyai nilai minimum 0,020 pada PT. Bumi Serpong Damai Tbk pada tahun 2017 dan nilai maksimum 3,720 PT. Plaza Indonesia Realty Tbk pada tahun 2013 sedangkan nilai rata-rata (mean) 0,32053 dengan standar deviasi 0,505531 .

3. Dari sampel sebanyak 75, Arus Kas bebas mempunyai nilai minimum 84490346000 pada PT. Metropolitan Land Tbk pada tahun 2015 dan nilai maksimum 6109239577200000 PT. Bumi Serpong Damai Tbk pada tahun 2015 sedangkan nilai rata-rata (mean) 628635779454711,60 dengan standar deviasi 1354353995349307,000.

4. Dari sampel sebanyak 75, Debt to Equity Ratio mempunyai nilai minimum 0,240 pada PT. Duta Pertiwi Tbk pada tahun 2013 dan 2016 dan nilai maksimum 5,280 pada PT. Adhi Karya (Persero) Tbk pada tahun 2013 sedangkan nilai rata-rata (mean) 1,38587 dengan standar deviasi 1,208592.

5. Dari sampel sebanyak 75, Return On Asset mempunyai nilai minimum 0,010 pada PT. Plaza Indonesia Realty dan Pudjiati Prestige Tbk pada tahun 2013 dan 2017 dan nilai maksimum 0,220 pada PT. Bekasi Fajar Industrial Estate Tbk pada tahun 2013 sedangkan nilai rata-rata (mean) 0,7573 dengan standar deviasi 0,43687 .

6. Dari sampel sebanyak 75 , Nilai perusahaan mempunyai nilai minimum 0,290 pada PT. Pudjiati Prestige Tbk pada tahun 2017 dan nilai maksimum 11,950 pada PT. Plaza Indonesia Realty Tbk pada tahun 2017 sedangkan nilai rata-rata (mean) 2,67680 dengan standar deviasi 2,146805.

Uji asumsi klasik. Uji asumsi klasik ada empat yaitu uji normalitas, uji multikolinieritas, uji autokorelasi, dan uji heteroskedastisitas.

Uji normalitas. Gambar 1 menunjukkan bahwa garis kurva cenderung simetri (U) dan membentuk lonceng terbalik, sehingga dapat disimpulkan bahwa data penelitian ini berdistribusi secara normal.

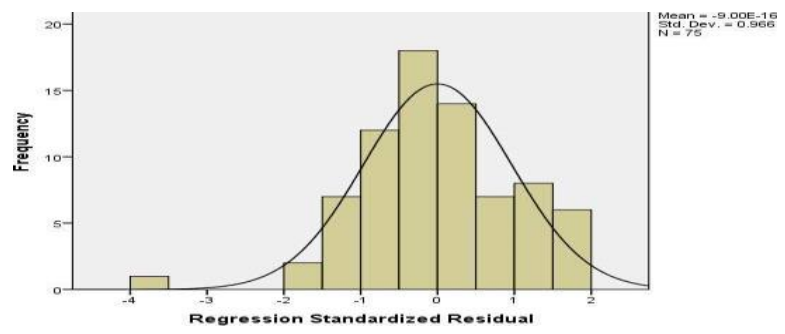

Gambar 1. Histogram normalitas

Gambar 2 menunjukkan bahwa titik-titik menyebar di sekitar garis normal dan mengikuti arah garis diagonal sehingga menunjukkan bahwa data berdistribusi secara normal. Untuk memastikan data berdistribusi normal atau tidak, digunakan analisis statistik grafik. Analisis statistik yang digunakan adalah Uji Kolmogorov-Smirnov dapat dilihat pada tabel dibawah ini sebagai berikut: 


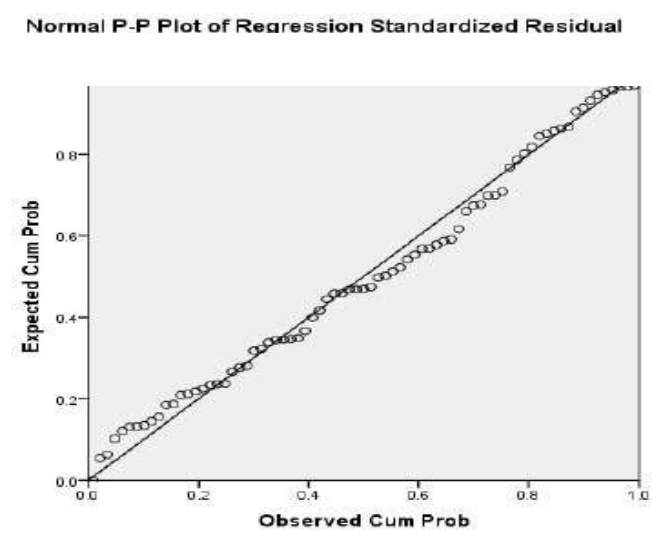

Gambar 2.P-Plot normalitas

Uji Kolmogorov-Smirnov. Tabel3 menunjukkan bahwa nilai Asymp. Sig. (2-tailed) diatas 0,05 atau diatas 5\% yakni 0,826, maka dapat disimpulkan bahwa hasil Uji Normalitas Kolmogorov-Smirnov menunjukkan bahwa data berdistribusi secara normal.

Tabel 3. Uji Kolmogorov-Smirnov

\begin{tabular}{llr}
\hline & & Unstandardized Residual \\
\hline $\mathrm{N}$ & Mean & 75 \\
Normal Parameters a,b & Std. Deviation & $0 \mathrm{E}-7$ \\
& Absolute & 0.40293259 \\
Most Extreme Differences & Positive & 0.072 \\
& Negative & 0.072 \\
Kolmogorov-Smirnov Z & & -0.060 \\
Asymp. Sig. (2-tailed) & & 0.628 \\
& & 0.826 \\
\hline
\end{tabular}

Uji multikolinearitas. Tabel 4 menunjukkan bahwa nilai tolerance variabel earning per share sebesar 0,611; dividend payout ratio sebesar 0,862; arus kas bebas sebesar 0,590; debt to equity ratio sebesar 0,629; return on assets sebesar 0,624 lebih besar dari 0,1 . Nilai VIF untuk earning per share sebesar 1,635; dividend payout ratio sebesar 1,160; arus kas bebas sebesar 1,695; debt to equity ratio sebesar 1,590; return on assets sebesar 1,604 lebih kecil dari 10, maka dapat ditarik kesimpulan bahwa data tidak terjadi masalah multikolinearitas.

Tabel 4. Uji multikolinearitas

\begin{tabular}{lrrrrr}
\hline \multirow{2}{*}{ Model } & \multicolumn{2}{c}{ Unstandardized Coefficients } & \multicolumn{2}{c}{$\begin{array}{c}\text { Standardized } \\
\text { Coefficients }\end{array}$} & \multicolumn{2}{c}{ Collinearity Statistics } \\
\cline { 2 - 6 } & B & Std. Error & \multicolumn{1}{c}{ Beta } & Tolerance & VIF \\
\hline (Constant $)$ & -0.802 & 0.304 & & & \\
EPS & 0.020 & 0.010 & 0.214 & 0.611 & 1.635 \\
DPR & 0.818 & 0.195 & 0.366 & 0.862 & 1.160 \\
Aruskas bebas & $8.024 \mathrm{E}-010$ & 0.000 & 0.028 & 0.590 & 1.695 \\
DER & 0.630 & 0.136 & 0.472 & 0.629 & 1.590 \\
ROA & 3.805 & 0.779 & 0.500 & 0.624 & 1.604 \\
\hline
\end{tabular}

Ujiautokorelasi. Tabel 5 menunjukkan bahwa nilai $D W$ sebesar 2,049, dengan melihat tabel Uji Durbin - Watson dapat tingkat signifikan 5\% untuk jumlah variabel bebas = 
3 dan jumlah sampel $=75$ diperoleh nilai $\mathrm{du}=1.7698$ dan $\mathrm{dl}=1.4866$, sehingga dapat disimpulkan bahwa data terbebas dari masalah autokorelasi karena du $<\mathrm{dw}<4-\mathrm{du}(1.7698$ $<2,049<2,2302)$.

Tabel 5 Uji autokorelasi

\begin{tabular}{lccccc}
\hline Model & R & R Square & Adjusted RSquare & Std. ErroroftheEstimate & Durbin-Watson \\
\hline 1 & $0.741^{\text {a }}$ & 0.549 & 0.516 & 0.41728 & 2.049 \\
\hline
\end{tabular}

Uji heterokedastisitas. Tabel SQRT diatas menunjukkan bahwa nilai signifkan variabel earning per share sebesar 0,782; dividend payout ratio sebesar 0,054; arus kas bebas sebesar 0,122; debt to equity ratio sebesar 0,2 dan return on assets sebesar 0,077 lebih besar dari 0,05 , sehingga dapat disimpulkan tidak terjadi masalah heterokedastisitas.

Tabel 6. Uji heterokedastisitas

\begin{tabular}{|c|c|c|c|c|c|}
\hline \multirow[t]{2}{*}{ Model } & \multicolumn{2}{|c|}{ Unstandardized Coefficients } & \multirow{2}{*}{$\begin{array}{c}\begin{array}{c}\text { Standardized } \\
\text { Coefficients }\end{array} \\
\text { Beta }\end{array}$} & \multirow[t]{2}{*}{$\mathbf{t}$} & \multirow[t]{2}{*}{ Sig. } \\
\hline & B & Std. Error & & & \\
\hline Constant & -0.062 & 0.172 & & -0.361 & 0.719 \\
\hline EPS & -0.002 & 0.006 & -0.038 & -0.278 & 0.782 \\
\hline DPR & 0.216 & 0.111 & 0.227 & 1.957 & 0.054 \\
\hline Aruskasbebas & $-2.688 \mathrm{E}-009$ & 0.000 & -0.220 & -1.568 & 0.122 \\
\hline DER & 0.100 & 0.077 & 0.176 & 1.295 & 0.200 \\
\hline ROA & 0.793 & 0.441 & 0.245 & 1.796 & 0.077 \\
\hline
\end{tabular}

Dependent Variable : ABS_Y2

Persamaan Regresi. Pengujian hipotesis yang digunakan dalam penelitian adalah dengan menggunakan analisis regresi linier berganda. Model regresi yang digunakan disajikan pada Tabel 7. Berdasarkan Tabel 7 diperoleh rumus regresi sebagai berikut : $P B V=-0,802+0,02 E P S+0,818 D P R+0,8024 A R U S K A S B E B A S+0,63 D E R+0,3805 R O A$ Makna dari persamaan regresi linier berganda diatas adalah :

- Nilai konstanta sebesar -0,802 artinya jika variabel Earning Per Share, Dividend Payout Ratio, Arus Kas Bebas, Debt To Equity Ratio, dan Return On Assets dianggap nol atau tidak, maka nilai perusahaan adalah sebesar $-0,802$ kali.

- Nilai koefisien Earning Per Share adalah 0,02. Ini menunjukkan bahwa setiap peningkatan Earning Per Share satu kali maka nilai perusahaan akan mengalami peningkatan sebesar $0,02 \mathrm{kali}$.

- Nilai koefisien Dividend Payout Ratio adalah 0,818. Ini menunjukkan bahwa setiap peningkatan Dividend Payout Ratio satu kali maka nilai perusahaan akan mengalami peningkatan sebesar 0,818 kali.

- Nilai koefisien Arus Kas Bebas adalah 0,8024. Ini menunjukkan bahwa setiap peningkatan Arus Kas Bebas satu kali maka nilai perusahaan akan mengalami peningkatan sebesar 0,8024 kali.

- Nilai koefisien Debt To Equity Ratio adalah 0,63. Ini menunjukkan bahwa setiap peningkatan Debt To Equity Ratio satu kali maka nilai perusahaan akan mengalami peningkatan sebesar 0,63 kali.

- Nilai koefisien Return On Assets adalah 0,3805. Ini menunjukkan bahwa setiap peningkatan Return On Assets satu kali maka nilai perusahaan akan mengalami peningkatan sebesar 0,3805 kali. 
Tabel 7. Persamaan regresi

\begin{tabular}{|c|c|c|c|c|c|}
\hline \multirow{2}{*}{ Model } & \multicolumn{2}{|c|}{ Unstandardized Coefficients } & \multirow{2}{*}{$\begin{array}{c}\text { Standardized } \\
\text { Coefficients }\end{array}$} & \multirow{2}{*}{$\mathbf{t}$} & \multirow{2}{*}{ Sig. } \\
\hline & B & Std.Error & & & \\
\hline Constant & -0.802 & 0.304 & & -2.640 & 0.010 \\
\hline EPS & 0.020 & 0.010 & 0.214 & 2.066 & 0.043 \\
\hline DPR & 0.818 & 0.195 & 0.366 & 4.196 & 0.000 \\
\hline ArusKasBebas & $8.024 \mathrm{E}-010$ & 0.000 & 0.028 & 0.265 & 0.792 \\
\hline DER & 0.630 & 0.136 & 0.472 & 4.625 & 0.000 \\
\hline ROA & 3.805 & 0.779 & 0.500 & 4.885 & 0.000 \\
\hline
\end{tabular}

Dependent Variable :NilaiPerusahaan

Koefisien determinasihipotesis. Berdasarkan hasil uji koefisien determinasi pada Tabel 8 diperoleh nilai Adjusted $R$ Square $\left(\mathrm{R}^{2}\right)$ koefisien determinasi sebesar 0,516 atau sebesar 51,6 \%, maka dapat disimpulkan bahwa variabel earning per share, divident payout ratio, debt to equityratio, arus kas bebas, dan return on assets dapat menjelaskan model nilai perusahaan sebesar 51,6\% dan sisanya sebesar 48,4\% dipengaruhi oleh variabel lain.

Tabel 8. Koefisien determinasi

\begin{tabular}{llccc}
\hline Model & $\mathbf{R}$ & RSquare & Adjusted RSquare & Std. ErroroftheEstimate \\
\hline 1 & $0.741^{\mathrm{a}}$ & 0.549 & 0.516 & 0.41728 \\
\hline
\end{tabular}

Uji Secara Simultan (Uji F). Tabel Uji F diatas diperoleh uji signifikan simultan menghasilkan Fhitung sebesar 16,769 dengan nilai signifikan 0,000; sedangkan nilai Ftabel adalah sebesar 2,35 dengan nilai signifikan 0,05. Dengan demikian maka Fhitung > Ftabel yaitu 16,769> 2,35, sehingga dapat disimpulkan bahwa variabel Earning Per Share, Divident Payout Ratio, Debt To Equity Ratio, Arus Kas Bebas, dan Return On Assets secara bersamasama berpengaruh signifikan terhadap nilai perusahaan pada perusahaan property dan real estate yang terdaftar di Bursa Efek Indonesia tahun 2013 -2017.

Tabel 9. Uji Statistik F

\begin{tabular}{lrrrrr}
\hline \multicolumn{1}{c}{ Model } & SumofSquares & \multicolumn{1}{c}{ Df } & MeanSquare & F & Sig. \\
\hline Regression & 14.599 & 5 & 2.920 & 16.769 & $0.000^{\mathrm{b}}$ \\
Residual & 12.014 & 69 & 0.174 & & \\
Total & 26.613 & 74 & & & \\
\hline
\end{tabular}

Uji Secara Individu (Uji-t). Tabel 10 menunjukkan bahwa :

- Earning Per Share diketahui mempunyai $t_{\text {hitung }}$ sebesar 2.066 dengan signifikansi 0,043; sedangkan $t_{\text {tabel }}$ sebesar 1.99444 dengan nilai signifikan 0,05. Maka $t_{\text {hitung }}>t_{\text {tabel }}$, yaitu $2.066>1.99444$, sehingga disimpulkan bahwa variabel earning per share secara parsial berpengaruh positif dan signifikan terhadap nilai perusahaan.

- Dividend payout ratio diketahui mempunyai $t_{\text {hitung }}$ sebesar 4.196 dengan signifikansi 0,000. Sedangkan $t_{\text {tabel }}$ sebesar 1.99444 dengan nilai signifikan 0,05. Dengan demikian $t_{\text {hitung }}>t_{t a b e l}$, yaitu $4.196>1.99444$, sehingga disimpulkan bahwa variabel dividend payout ratio secara parsial berpengaruh positif dan signifikan terhadap nilai perusahaan.

- Arus kas diketahui mempunyai $t_{\text {hitung }}$ sebesar 0.265 dengan signifikansi 0,792. Sedangkan $\mathrm{t}_{\text {tabel }}$ sebesar 1.99444 dengan nilai signifikan 0,05. Dengan demikian $t_{\text {hitung }}<t_{\text {tabel }}$, yaitu $0.265<1.99444$, sehingga disimpulkan bahwa variabel arus kas secara parsial tidak berpengaruh signifikan terhadap nilai perusahaan. 
- Debt to equity ratio diketahui mempunyai $t_{\text {hitung }}$ sebesar 4.625 dengan signifikansi 0,000 . Sedangkan $t_{\text {tabel }}$ sebesar 1.99444 dengan nilai signifikan 0,05. Dengan demikian $t_{\text {hitung }}>$ $\mathrm{t}_{\text {tabel}}$, yaitu $4.625>1.994444$, sehingga disimpulkan bahwa variabel debt to equity ratio secara parsial berpengaruh positif dan signifikan terhadap nilai perusahaan.

- Return on asset diketahui mempunyai thitung sebesar 4.885 dengan signifikansi 0,000. Sedangkan $t_{\text {tabel }}$ sebesar 1.99444 dengan nilai signifikan 0,05. Dengan demikian $t_{\text {hitung }}>$ $\mathrm{t}_{\text {tabel}}$, yaitu $4.885>1.99444$, sehingga disimpulkan bahwa variabel return on asset secara parsial berpengaruh positif dan signifikan terhadap nilai perusahaan.

Tabel 10. Uji-t

\begin{tabular}{lrrrrrr}
\hline \multirow{2}{*}{ Model } & \multicolumn{2}{c}{ Unstandardized Coefficiens } & Standardized Coefficients & \multirow{2}{*}{ t } & \multirow{2}{*}{ Sig. } \\
\cline { 2 - 5 } & \multicolumn{1}{c}{ B } & Std.Error & Beta & & -2.640 & 0.010 \\
Constant & -0.802 & 0.304 & & 0.214 & 2.066 & 0.043 \\
EPS & 0.020 & 0.010 & & 0.366 & 4.196 & 0.000 \\
DPR & 0.818 & 0.195 & & 0.028 & 0.265 & 0.792 \\
ArusKasBebas & $8.024 \mathrm{E}-010$ & 0.000 & & 0.472 & 4.625 & 0.000 \\
DER & 0.630 & 0.136 & & 0.500 & 4.885 & 0.000 \\
ROA & 3.805 & 0.779 & & & &
\end{tabular}

\subsection{Pembahasan}

Pengaruh variabel earning per share terhadap price to book value ratio (PBV). Penelitian ini menunjukkan nilai koefisien varibel Return On Assets (ROA) berpengaruh positif dan signifikansi terhadap Nilai Perusahaan (PBV). Hasilnya sejalan dengan penelitian Marlina (2013), bahwa Earning Per Share (EPS) berpengaruh positif dan signifikan terhadap Nilai Perusahaan, Akan tetapi, penelitian ini tidak sesuai dengan penelitian Kurniawati (2018), bahwa nilai perusahaan Earning Per Share nya berpengaruh negative. Hal ini menjelaskan bahwa perusahaan yang memiliki EPS tinggi maka dividen yang dibagikan kepada pemegang saham juga tinggi. Dan para investor pasti akan tergiur karena pengaruhnya positif untuk Nilai Perusahaan. Berdasarkan hipotesis pertama, EPS berpengaruh signifikan terhadap Nilai Perusahaan dapat diterima.

Pengaruh variabel kebijakan dividen terhadap price to book value ratio (PBV). Penelitian ini menunjukkan nilai koefisien variabel kebijakan dividen berpengaruh positif dan signifikansi terhadap Nilai Perusahaan (PBV). Hasilnya sejalan dengan penelitian Ayem dan Nugroho (2016), bahwa kebijakan dividen berpengaruh positif dan signifikan terhadap Nilai Perusahaan. Akan tetapi, penelitian ini tidak sesuai dengan penelitian Ali \& Miftahurrohman (2014), bahwa nilai perusahaan, kebijakan dividen nya berpengaruh negative dan tidak signifikan, karena perusahaan yang memiliki keuntungan yang lebih akan membagikan keuntungan tersebut kepada pemegang saham sesuai proporsi yang telah ditetapkan. Hal ini menjelaskan bahwa dengan membayar dividen secara tunai maka faktor yang mempengaruhi kebijakan dividen meningkat dan perusahaan dapat menarik para investor untuk mencari dividen. Semakin banyak dana yang ada untuk investasi maka tingkat pertumbuhan di masa mendatang lebih tinggi sehingga dapat meningkatkan harga saham dan dapat membantu memelihara nilai perusahaan. Tingginya kebijakan dividen maka semakin efisien nilai perusahaan dan juga sebaliknya. Berdasarkan hipotesis kedua, kebijakan dividen berpengaruh signifikan terhadap nilai perusahaan dapat diterima.

Pengaruh variabel free cash flow terhadap price to book value ratio (PBV). Penelitian ini menunjukkan nilai koefisien variabel Arus Kas tidak berpengaruh signifikansi terhadap Nilai Perusahaan (PBV). Hasilnya sejalan dengan penelitian Naini dan Wahidahwati (2014), bahwa free cash flow berpengaruh negative dan tidak signifikan terhadap nilai perusahaan. Hal ini bisa terjadi karena perusahaan mungkin menahan free cash flow untuk tetap berada dibawah kendali si perusahaan dan tidak dibagikan kepada pemegang saham. 
Kinerja Perusahaan digunakan untuk mengukur laporan keuangan perusahaan agar mereka tahu bagaimana proses arus kas di perusaahaan tersebut (Lestari dan Sari, 2015). Digunakan regresi linear berganda dalam metode analisis ini. Berdasarkan hipotesis ketiga, arus kas berpengaruh signifikan terhadap nilai perusaahan tidak dapat diterima.

Pengaruh variabel debt to equity ratio terhadap price to book value ratio (PBV). Penelitian ini menunjukkan nilai koefisien variabel Debt to Equity Ratio (DER) berpengaruhpositif dan signifikansi terhadap Nilai Perusahaan. Hasilnya sejalan dengan penelitian Hermuningsih (2013) yang menyatakan bahwa leverage berpengaruh positif dan signifikan terhadap Nilai Perusahaan. Kebalikannya, jika leverage yang tinggi menunjukkan suatu perusahaan menggunakan hutang sebagai struktur modal mereka, maka leverage nya memiliki pengaruh negative terhadap Nilai Perusahaan, Isynuwadhana (2017). Berdasarkan hipotesis keempat, Debt To Equity Ratio berpengaruh signifikan terhadap Nilai Perusahaan dapat diterima.

Pengaruh variabel return on assets terhadap price to book value (PBV). Penelitian ini menunjukkan nilai koefisien variabel Return on assets (ROA) berpengaruh positif dan signifikansi terhadap Nilai Perusahaan. Hasilnya sejalan dengan penelitian Wahyuningsih dan Widowati (2016) yang menyatakan bahwa Return on assets berpengaruh positif dan signifikan terhadap Nilai Perusahaan. Sebaliknya, hasil penelitian ini tidak konsisten dengan hasil penelitian Salempang et al. (2016). Tinggi rendahnya ROA tergantung pada pengelolaan aset perusahaan oleh manajemen yang menggambarkan efisiensi operasional perusahaan. Semakin tinggi ROA semakin efisien perusahaan dan juga sebaliknya. Berdasarkan hipotesis kelima, Return On Assets berpengaruh signifikan terhadap Nilai Perusahaan dapat diterima.

\section{KESIMPULAN DAN SARAN}

\subsection{Kesimpulan}

Berdasarkan pengujian 6 (enam) hipotesis antara lainEarning Per Share, Dividend Payout Ratio, Debt To Equity Ratio, Return On Assets berpengaruh positif dan signifikan terhadap Price To Book Value sedangkan Free Cash Flow tidak berpengaruh dan signifikan.

\subsection{Saran}

Jika penelitian ini ingin diteliti lebih mendalam lagi maka alangkah baiknya menggunakan nilaivariabel tata kelola perusahaan yang baik (good corporate governance) atau sering disebut GCG, likuiditas (liquidity), ukuran perusahaan (company size).

\section{DAFTAR PUSTAKA}

Ahmad, R., \& Ali, H. (2014). Manajemen Keuangan Modern, Edisi Pertama, Cetakan Pertama. Jakarta: Mitra Wacana Media.

Ali, H., \& Miftahurrohman. (2014). Pengaruh struktur kepemilikan saham, kebijakan dividen dan kebijakan hutang terhadap nilai perusahaan (studi pada perusahaan yang terdaftar di bei). Etikonomi, 13(2). 148-163. https://doi.org/10.15408/etk.v13i2.1883

Anwar, S. (2014). Metodologi Penelitian Bisnis, cetakan Keempat. Jakarta: Salemba Empat.

Ayem, S., \& Nugroho, R. (2016). Pengaruh profitabilitas, struktur modal, kebijakan dividen, dan keputusan investasi terhadap nilai perusahaan (Studi kasus perusahaan manufaktur yang go publik di Bursa Efek Indonesia) periode 2010-2014. Jurnal Akuntansi, 4(1),

$31-40$. https://jurnalfe.ustjogja.ac.id/index.php/akuntansi/article/view/125 
Benardi, J. (2010). Pengaruh cash flow terhadap leverage dan investasi serta dampaknya terhadap nilai perusahaan. Jurnal Ekonomi dan Kewirausahaan, 10(2), 93-108. https://ejurnal.unisri.ac.id/index.php/Ekonomi/article/view/357

Darmadji, T., \& Fakhruddin, H. M. (2012). Pasar Modal di Indonesia, Edisi Ketiga. Jakarta: Salemba Empat.

Dewi, I. A. M. C., \& Putra, I. W. (2017). Free cash flow sebagai pemoderasi pengaruh earnings management dan kebijakan dividen pada nilai perusahaan. E-Jurnal Akuntansi, $18(2)$,

1259-1285. https://ojs.unud.ac.id/index.php/Akuntansi/article/view/24412

Ghozali, I. (2013). Aplikasi analisis multivariate dengan program SPSS. Semarang: Badan Penerbit Universitas Diponegoro.

Harrison, W. T., Horngren, C. T., Thomas, C. W., \& Suwardy, T. (2013). Akuntansi Keuangan - IFRS Jilid 2, Ed.8. Jakarta: Erlangga.

Hermuningsih, S. (2013). Pengaruh profitabilitas, growth opportunity, struktur modal terhadap nilai perusahaan pada perusahaan publik di Indonesia. Buletin Ekonomi Moneter dan Perbankan, 16(2), 127-148. https://doi.org/10.21098/bemp.v16i2.27

Hery, S. E. (2017). Analisis Kinerja Manajemen. Jakarta: Gramedia Widiasarana.

Indriani, A. (2018). Pengaruh indeks corporate governance, leverage, profitabilitas dan ukuran perusahaan terhadap nilai perusahaan (Studi Empiris pada perusahaan yang terdaftar konsisten dalam penilaian CGPI periode 2012-2016). Skripsi: Fakultas Ekonomika dan Bisnis Universitas Diponegoro. http://eprints.undip.ac.id/62969/

Jusriani, I. F. (2013). Analisis pengaruh profitabilitas, kebijakan dividen, kebijakan utang, dan kepemilikan manajerial terhadap nilai perusahaan (Studi empiris pada perusahaan manufaktur yang terdaftar di Bursa Efek Indonesia periode 2009 -2011). Skripsi: Fakultas Ekonomika dan Bisnis Universitas Diponegoro. http://eprints.undip.ac.id/39008/

Kamaludin, I. R. (2012). Manajemen Keuangan: Konsep Dasar dan Penerapannya. Bandung: Mandar Maju.

Kurniawati, F. F. (2018). Pengaruh Profitabilitas, Leverage dan Earning per Share (EPS) terhadap nilai perusahaan (Studi kasus pada perusahaan Sub Sektor Hotel, Restoran dan Pariwisata yang Terdaftar di BEI Periode 2012-2016). Skripsi: Fakultas Ekonomi Universitas 17 Agustus 1945 Surabaya. http://repository.untag-sby.ac.id/345/

Lestari, R. M. E. L. E., \& Sari, P. P. (2015). Komparasi pengaruh arus kas terhadap nilai perusahaan antara PT Hero Supermarket Tbk dengan PT Matahari Putra Prima Tbk. Jurnal Ilmiah Akuntansi Fakultas Ekonomi, 1(1), 33-37. https://doi.org/10.34204/jiafe.v1i1.294

Mardasari, B. R. (2014). Pengaruh insider ownership, kebijakan hutang dan free cash flow terhadap nilai perusahaan melalui kebijakan dividen. Jurnal Ilmu Manajemen, 2(4), 1807-1820. https://jurnalmahasiswa.unesa.ac.id/index.php/jim/article/view/12400

Margaretha, F. (2011). Manajemen keuangan untuk manajer nonkeuangan. Jakarta: Erlangga.

Marlina, T. (2013). Pengaruh earning per share, return on equity, debt to equity ratio dan size terhadap price to book value. Jurnal Ilmiah Akuntansi Kesatuan, 1(1), 59-72. http://digilib.mercubuana.ac.id/manager/t\%21@file_artikel_abstrak/Isi_Artikel_7156 53482132.pdf

Murhadi, W. R. (2013). Analisis laporan keuangan: Proyeksi dan valuasi saham. Jakarta: Salemba Empat.

Musthafa, H. (2017). Manajemen Keuangan. Yogyakarta: Penerbit Andi.

Naini, D. I., \& Wahidahwati. (2014). Pengaruh free cash flow dan kepemilikan institusional terhadap kebijakan hutang dan nilai perusahaan. Jurnal Ilmu dan Riset Akuntansi, 3(4), 1-17. http://garuda.ristekdikti.go.id/documents/detail/524453 
Najmudin. (2011). Manajemen keuangan dan aktualisasi Syariyyah Modern. Yogyakarta: Penerbit Andi.

Nisa, I. K. (2017). Pengaruh profitabilitas, leverage, kepemilikan manajerial terhadap nilai perusahaan dengan pengungkapan corporate social responsibility (CSR) sebagai variabel moderating (Studi empiris perusahaan manufaktur yang terdaftar di Bursa Efek Indonesia dari Tahun 2012-2015). Skripsi: Fakultas Ekonomi Universitas Negeri Semarang. https://lib.unnes.ac.id/29817/

Nurminda, A., Isynurwardhana, D., \& Nurbaiti, A. (2017). Pengaruh profitabilitas, leverage, dan ukuran perusahaan terhadap nilai perusahaan (Studi pada Perusahaan Manufaktur Sub Sektor Barang dan Konsumsi yang Terdaftar di Bursa Efek Indonesia Periode 2012-2015). eProceedings of Management, 4(1), 542-549. https://libraryeproceeding.telkomuniversity.ac.id/index.php/management/article/view/ 4484

Pantow, M. S. R., Murni, S., \& Trang, I. (2015). Analisa pertumbuhan penjualan, ukuran perusahaan, return on asset, dan struktur modal terhadap nilai perusahaan yang tercatat di Indeks LQ 45. Jurnal EMBA: Jurnal Riset Ekonomi, Manajemen, Bisnis dan Akuntansi,3(1), 961-971. https://ejournal.unsrat.ac.id/index.php/emba/article/view/7801

Priyatno, D. (2012). Cara kilat belajar analisis data dengan SPSS 20. Yogyakarta: Penerbit Andi.

Purwanto, A. H. S. (2017). Manajemen Investasi: Kiat-Kiat Sukses Berinvestasi Saham Paduan Prakis bagi Pemula. Jakarta: Mitra Wacana Media.

Salempang, L. E., Sondakh, J. J., \& Pusung, R. J. (2016). Pengaruh return on assets, debt to equity ratio, pertumbuhan penjualan terhadap nilai perusahaan pada sektor real estate dan property yang terdaftar di BEI 2013-2014. Jurnal Berkala Ilmiah, 16(3), 813-824. https://ejournal.unsrat.ac.id/index.php/jbie/article/view/13577

Samryn, L. M. (2015). Pengantar akuntansi-Metode akuntansi untuk elemen laporan keuangan diperkaya dengan perspektif IFRS \& Perbankan. Edisi Pertama. Jakarta: PT. Raja Grafindo Persada.

Sjahrial, D. (2012). Pengantar Manajemen Keuangan. Jakarta: Mitra Wacana Media.

Sugiyono. (2010). Metode Penelitian Pendidikan Pendekatan Kuantitatif, Kualitatif, dan R\&D. Bandung: Alfabeta.

Sugiyono. (2016). Metode Penelitian Kuantitatif, Kualitatif dan R\&D. Bandung: PT Alfabet.

Sujarweni, W. (2016). Pengantar Akuntansi. Yogyakarta: Pustaka Baru Press.

Utari, D., Purwanti, A., \& Prawironegoro, D. (2016). Akuntansi Manajemen: Pendekatan Praktis. Edisi keempat. Jakarta: Mitra Wacana Media.

Wahyuningsih, P., \& Widowati, M. (2016). Analisis ROA dan ROE terhadap nilai perusahaan dengan corporate social responsibility sebagai variabel moderating (Studi pada perusahaan BUMN yang terdaftar di BEI Periode 2010-2013). Jurnal Ekonomi STIE Semarang, 8(3), 83-102. http://jurnal3.stiesemarang.ac.id/index.php/jurnal/article/view/53

Yuniningsih. (2018). Dasar-Dasar Manajemen Keuangan. Sidoarjo: Indomedia Pustaka.

Zulganef, M. (2013). Metode Penelitian Sosial dan Bisnis. Yogyakarta: Graha Ilmu. 